\title{
ARE THE CHALLENGES IN THE PROCESSING OF BUILDING PERMITS A PRECURSOR FOR DEVELOPMENT OF ILLEGAL STRUCTURES IN GHANA?
}

\author{
Stephen Agyeman ${ }^{*}$ Herbert Abeka ${ }^{* *} \&$ Sampson Assiamah ${ }^{* * *}$
}

Procuring building permit in Ghana possess a great challenge despite government effort in addressing this problem through the introduction of new land regulations, integration of the land agencies and emergence of the one-stop shop. The delays now serve as a precursor for issuance of false permits by so called middlemen and the development of unauthorized structures by some unscrupulous developers. This paper takes a retrospective look at inherent challenges in the acquisition of building permits in Ghana and how that contribute significantly to mushrooming of illegal structures in most of the major towns in the country. The intrinsic challenges which this paper identified through descriptive research using structured interviews include: lack of integrated central database management system for permit agencies and analogous institutions involved in the permit processing system, too many processing steps, increased cost of construction and loss of value due to bureaucratic delays, lack of coordination between the land agencies and the local authorities, inappropriate feedback systems among others. Redesigning the current permit system by integrating all the agencies involved in the building permit acquisition process to a central database management system for sustainable development is a highly favored option.

INTRODUCTION.

A. $\quad$ Overview of the Building Permit Acquisition Process ............. 339

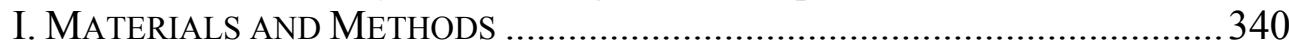

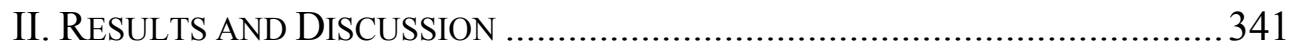

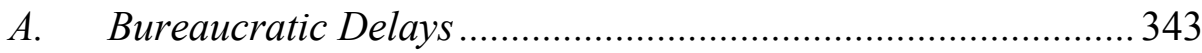

B. $\quad$ Data availability, Accessibility and Validity ........................... 344

C. Lack of Coordination Between the Land Agencies and the Local

\footnotetext{
* Lecturer, Department of Civil Engineering, Sunyani Polytechnic, Sunyani, Ghana, research fields: building permits, public transportation, traffic simulations and animations, and road traffic accidents analysis.

${ }^{* *}$ Sunyani Polytechnic, Sunyani, Ghana.

*** Sunyani Polytechnic, Sunyani, Ghana.

The researchers would like to acknowledge the support of SEM and SWM Assemblies Officials especially the TCPD Officers, Municipal Engineers, Staff of the Building Inspectorate Division; Regional Lands Commission Directorate, and all interviewees for their various inputs during the data collection stage.
} 
D. Inadequate Number of Staff for Field Inspection and Monitoring.

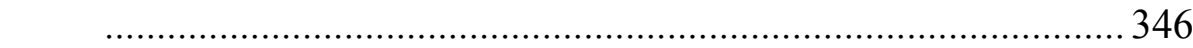

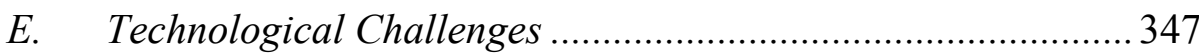

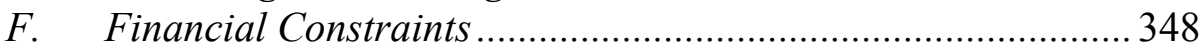

G. Poor Feedback Systems ......................................................... 349

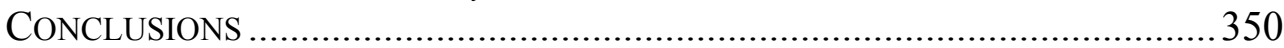

\section{INTRODUCTION}

Authorities in Ghana are confronted with the challenge of illegal structural developments. ${ }^{1,2,3,4}$ The problem spans from high-rising buildings to the miniature kiosks. ${ }^{5}$ These unfortunate developments are taking place every now and then in the night and during the day, on public and on private lands as well. Most at times, the city authorities think the only remedial measure is demolition of these illegal structures as recently happened in Tema (Agyei Kwadow in 2014), Accra (Old Fadama-Sodom and Gomorrah in 2015) and Kumasi (Adeshiman in 2014). The results of these demolitions on the poor developers are quantitatively enormous. However, procuring building permit in Ghana possess a great challenge despite government effort in addressing this issue through the introduction of new land regulations, integration of the land agencies and emergence of the one-stop shop. ${ }^{6,7}$ The delays now serve as a precursor for issuance of false permits by so called middlemen and the development of unauthorized structures by some unscrupulous developers. Ghana ranked 151th position in the world in the easy of acquiring building permit rankings according to

\footnotetext{
${ }^{1}$ Botchway E., Afram S. O., \& Ankrah J., Building Permit Acquisition in Ghana: The Situation in Kumasi, 4(20) InTERnATIONAL InStitute OF SCIENCE, TeChNOLOGY AND EdUCATION (IISTE) 11-22 (2014). Available at http://www.iiste.org (last visited Mar. 01, 2016).

${ }^{2}$ Oppong R. A., \& Yeboah E., Empirical Examinations of Conflicts and Contradictions in Architecture, Land and Suburban Sprawl: The Case of Tamale, Ghana, 33(1) JOURNAL OF SCIENCE AND TECHNOLOGY 92-104 (2013). doi:org/10.4314/just.v33i1.10.

${ }^{3}$ Moullier T., Reforming Building Permits: Why is It Important and What Can IFC Really Do?, (Washington, D.C., USA: International Finance Corporation 2009).

${ }^{4}$ Freiku S. R., Ghana: Kumasi's Development Getting Worse, Chaotic, REPORT PUBLISHED FOR LOCAL GOVERNMENT AND ASSEMBLY DELIBERATION (Accra, Ghana: Ghana News Agency (GNA) 2003).

${ }^{5}$ Hammah N. K., Re-echoing Building Permits, PERMIT JOURNALS TO REVAMP PUBLIC CONSCIOUSNESS (2010). Available at http://wavesint.org/?s=re-echoing+building+permitsitle (last visited Feb. 25, 2016).

${ }^{6}$ Agyeman S., Asiedu S. B., \& Abeka H., Clients' Knowledge on Building Permit Acquisition Process-The Case of Sunyani East Municipal Assembly, 5(18) DEVELOPING COUNTRY STUDIES 8-20 (2015). Available at http://www.iiste.org (last visited Mar. 07, 2016).

${ }^{7}$ GOVERNMENT OF GHANA, LANDS COMMISSION ACT, (ACT 767) (Accra, Ghana: Ministry of Lands and Forestry 2008).
} 
World Bank and IFC. ${ }^{8}$ This position is highly unacceptable and unfavorable to attract perspective investors compared with Hong Kong (1st position) and Kenya who ranked best among African countries in the 35th position. This paper takes a retrospective look at inherent challenges in the acquisition of building permits in Ghana and how that contributes significantly to mushrooming of illegal structures in most of the major towns in the country.

\section{A. Overview of the Building Permit Acquisition Process}

The building permit acquisition process starts with the client buying and completing an application form at the local authority office with the site plan of the parcel to be developed. This site plan is usually copied from current master plans that contain the parcel in question. ${ }^{9}, 10$ This reproduction is done with all inherent errors in the preparation of the original plan. The application form is then completed by draughtsman (per the regulations, this should have been done by a Licensed Quantity Surveyor). The client submits the filled application forms with the building drawings for processing. The documents are vetted by a committee and necessary field inspection carried out by the building inspectors. Also ownership certification of parcel of interest at the lands commission is done. If the application passed, it is then forwarded to the Statutory Planning Committee (SPC) for final granting of the building permit.

The SPC however, meets quarterly or the committee members are called to meet based on the number of applications submitted within two months. If the application is not granted, the whole process has to be started over but no notification is given to the client. Monitoring the progress of the application by the client is always very difficult as it remained process oriented. The land ownership validation process can also delay the whole process as there are no efficient and modern land record systems in the lands

\footnotetext{
${ }^{8}$ WORLD BANK AND IFC, DEALING WITH CONSTRUCTION PERMITS (Washington, D.C., USA: World Bank Group and International Finance Corporation 2013). Available at $\mathrm{http}: / /$ www.doingbusiness.org/data/exploretopics/starting-a-business (last visited Feb. 20, 2016).

${ }^{9}$ Agyeman S., Asiedu S. B., \& Abeka H., Clients' Knowledge on Building Permit Acquisition Process-The Case of Sunyani East Municipal Assembly, 5(18) DEVELOPING COUNTRY STUDIES 8-20 (2015). Available at http://www.iiste.org (last visited Mar. 07, 2016). GOVERNMENT OF GHANA, LANDS COMMISSION ACT, (ACT 767) (Accra, Ghana: Ministry of Lands and Forestry 2008).

${ }^{10}$ Quartey R. Q., Performance Audit Report of the Auditor General on the Management of Building Permits at Ga East Municipal Assembly, REF. NO. AG.01/109/VOL.2/35 (Accra, Ghana: Parliament of Ghana 2011).
} 
commission to facilitate the search. Fig. $1^{11}$ is a flow diagram of the current building acquisition procedure in Ghana.

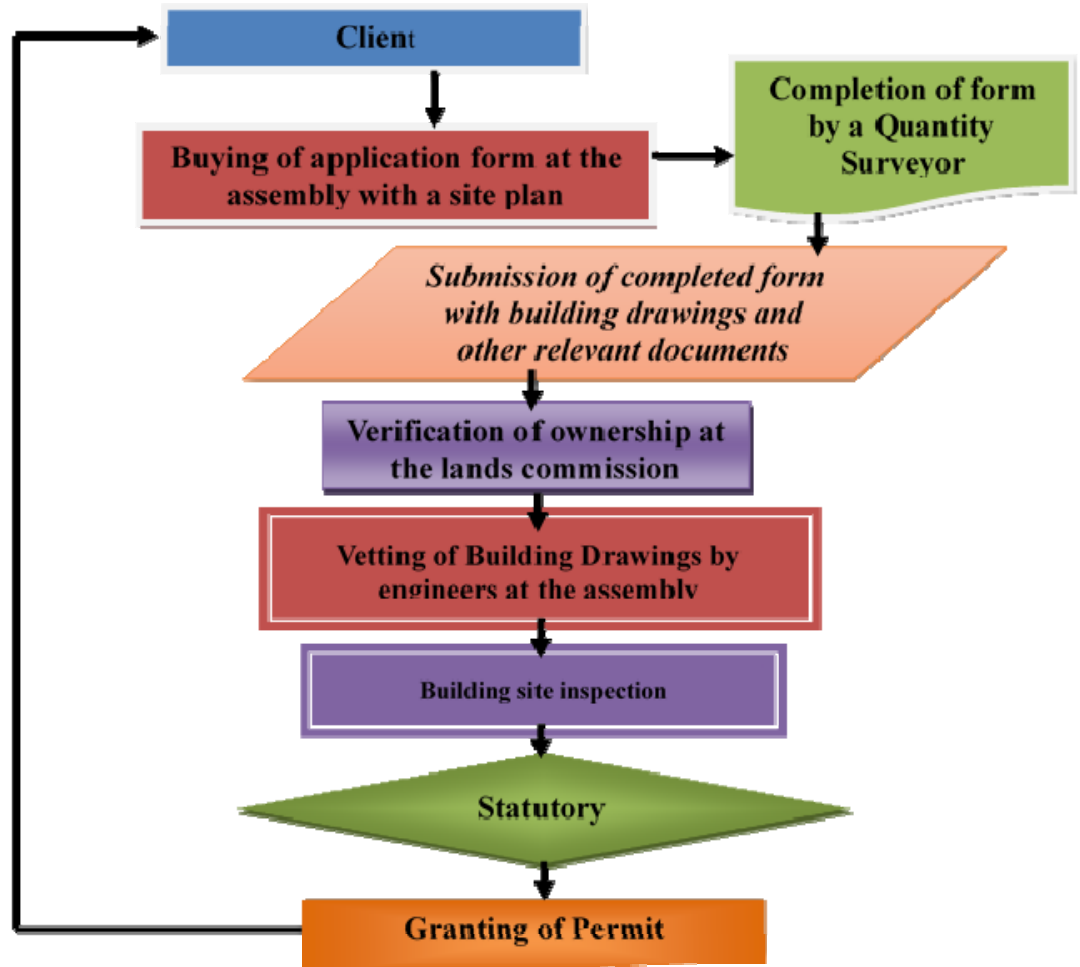

Figure 1 Flow chart showing the current building acquisition procedure in Ghana.

\section{MATERIALS AND METHODS}

The paper identifies intrinsic challenges in the building permit acquisition process using descriptive research and structured interviews. The study area was the Sunyani East Municipality (SEM) and Sunyani West Municipality (SWM) in Ghana. The Municipalities serve as transit town for travelers between northern and southern Ghana. Also, they are places of increased contract and cost management economic activity mostly resulting from the operations of a multinational mining company close to the town, and the presence of two universities and a polytechnic. In coming out with the challenges in the permit granting system, the researchers applied the

\footnotetext{
${ }^{11}$ Asiedu S. B., \& Agyeman S., Re-engineering the Processing of Building Permits to Control the Development of Unauthorized Structures in the Ghanaian Communities, PROCEEDINGS OF SUNYANI POLYTECHNIC LECTURE SERIES V. APPLIED SCIENCE AND TECHNOLOGY FOR DEVELOPMENT OF GHANA (Sunyani, Ghana: Sunyani Polytechnic 2009).
} 


\section{ARE THE CHALLENGES IN THE PROCESSING 341}

following key research procedures: Gather and analyze existing data to get a clear understanding of how the work processes currently operate within all the permit agencies in the municipalities. ${ }^{12}$ The researchers went to the municipalities and Lands Commission to obtained stakeholders' qualitative assessment of the existing process to assist in identifying process areas of key customer concerns. With the aim of ensuring the credibility of findings, interviews and personal observations were used to verify records, records and interviews were used to verify observations whereas records and observations were used to verify interviews. ${ }^{13}$

The survey instrument used in this research is questionnaire. Data gathering on the building permit acquisition process started with the interviewing of the Municipal TCPD Officers and Engineers for an understanding into the steps and challenges involved in the building permit acquisition process. Further interviews were conducted on 50 applicants (clients, consultants and contactors) who have been involved in the process of acquiring building permits, to verify the information on the permit acquisition challenges obtained previously from the officers of the assemblies. Lastly, field inspection officers from the assemblies, two officials from the Lands Commission were similarly interviewed. Purposive sampling technique was used to achieve the research objectives. Records, in the form of reports, forms, policies and regulations were reviewed for added information on the permit acquisition challenges within the Sunyani Municipalities.

\section{RESULTS AND DISCUSSION}

The summary of the results of the survey from 2012 to January 2014 in SEM and SWM are showed in Table 1. In the year 2012 from Table 1, the Sunyani East Municipal assembly received 237 building permit applications. Out of these 184 were considered. However in the SWM, 139 applications were received. Out of these, 138 were granted and only 1 application deferred. The approved applicants were 172 with only 12 applications deferred.

In all, 53 applications were not considered at all. The number of applications in SEM reduced drastically to more than 50\% while SWM applications increased by $57.5 \%$ in 2013. Out of this number, 171 applications were granted and 9 deferred in SEM. In SWM all the 327

\footnotetext{
${ }^{12}$ Kpamma E. Z., \& Adjei-Kumi T., Construction Permits and Flow of Projects within the Sunyani Municipality, Ghana, PROCEEDINGS INTERNATIONAL GROUP ON LEAN CONSTRUCTION (IGLC) 257-266 (Fortaleza, Brazil: IGLC 2013).

${ }^{13}$ ZUCKER P., WILSON K., \& TROYER S., DEVELOPMENT APPROVAL/PERMIT PROCESS 5-6 (Troy, Michigan: Zucker Systems 2008).
} 
applications were granted. As at 31 st of January 2014, 30 applications were received, out of these, 5 were deferred and 25 were awaiting decision in the SEM. Data was not available for SWM in 2014.

Table 1 Survey Results (Sunyani East and West).

\begin{tabular}{lllllllllll}
\hline \multirow{2}{*}{ Year } & \multicolumn{2}{c}{$\begin{array}{c}\text { Applications } \\
\text { Received }\end{array}$} & \multicolumn{2}{c}{$\begin{array}{c}\text { Applications } \\
\text { Considered }\end{array}$} & \multicolumn{2}{c}{$\begin{array}{c}\text { Applications Not } \\
\text { Considered }\end{array}$} & $\begin{array}{c}\text { Applications } \\
\text { Granted }\end{array}$ & \multicolumn{2}{c}{$\begin{array}{c}\text { Applications } \\
\text { Deferred }\end{array}$} \\
\cline { 2 - 10 } & SEM $^{\mathrm{a}}$ & SWM $^{\mathrm{b}}$ & SEM $^{\mathrm{a}}$ & $\mathrm{SWM}^{\mathrm{b}}$ & $\mathrm{SEM}^{\mathrm{a}}$ & $\mathrm{SWM}^{\mathrm{b}}$ & $\mathrm{SEM}^{\mathrm{a}}$ & SWM $^{\mathrm{b}}$ & SEM $^{\mathrm{a}}$ & SWM $^{\mathrm{b}}$ \\
\hline 2012 & 237 & 139 & 184 & 139 & 53 & 0 & 172 & 138 & 12 & 1 \\
2013 & 180 & 327 & 180 & 327 & 0 & 0 & 171 & 327 & 9 & 0 \\
2014 & 30 & - & 25 & - & 0 & - & Awaiting - & 5 & - \\
\hline
\end{tabular}

${ }^{\mathrm{a}} \mathrm{SEM}$-Sunyani East Municipality, ${ }^{\mathrm{b}} \mathrm{SWM}$-Sunyani West Municipality.

The average success rate was $82.3 \%$ for 417 applications for SEM and $99.8 \%$ for 466 applications for SWM. The deferral rate of $5.8 \%$ was obtained when 364 applications were considered in the SEM. The results showed high success rate. Prominent reasons cited for the delays and deferrals (Table 1) included, land ownership verification challenges (missing land title registration documents at the Lands Commission, wrong land allocation), re-zoning of existing land sectors and auxiliary documents such as fire and environmental permits. The extended duration of the permit processing, according to the interviews, could be blamed on factors such as missing application documents at the TCPD, delays in meeting of SPC and in signing of documents by technical officers. Results also revealed that, the staffs for the field inspection and monitoring at the TCPD Inspectorate Division were inadequate in number.

The interviews results from officials of the Lands Commission revealed the following challenges in the agency: lack of data integration for the processing of permits, lack of co-ordination between the Land Agencies and the Local Authorities, no mechanisms to check the validity of some of the documents submitted by clients, financial constraints, poor feedback systems, technological challenges; and land disputes, land acquisition and land tenure system challenge.

The 50 Applicants interviewed also complained of poor feedback systems, bureaucratic delays which lead to increase cost of construction and loss of value, cumbersome application procedures, multiple land sales and land disputes. Most of them believed that, re-engineering the whole process will be the most favored option. The following were the problems inherent in the existing building permit processing:

1. Bureaucratic delays which lead to increased cost of construction and loss of value;

2. Data accessibility for the processing is difficult; 
3. Lack of co-ordination between the Land Agencies and the Local Authorities;

4. No mechanisms to check the validity of some of the documents submitted by clients;

5. Search for ownership at the lands commission can be very cumbersome;

6. Inadequate number of staff for the field inspection and monitoring;

7. Lack of modern ways (using ICT) of keeping and retrieving land records at the lands commission;

8. Financial constraints;

9. Poor feedback systems.

\section{A. Bureaucratic Delays}

Generally, bureaucratic delays in building permit procurement lead to increased cost of construction and loss of value. ${ }^{14}$ According to Eyiah ${ }^{15}$ and World Bank ${ }^{16}$, developers find themselves interfaced with national, regional and district bureaucracies at all levels of a project to obtain building permits. Mensah and others ${ }^{17}$ also established that, most delays in establishing business in developing countries like Ghana occurred in securing land and in obtaining building permits. It was not surprising that, a workshop to review processes and procedures for granting building and development permits by the TCPD under the Land Administration Project (LAP) held in Accra on July 28, 2008, by 38 planners and works engineers of MMDAs (Municipal, Metropolitan and District Assemblies) recommended a total review of the existing permit acquisition procedures. ${ }^{18}$ Currently, the permit duration for processing building permit is 220 working days. ${ }^{19}$ In other parts

\footnotetext{
${ }^{14}$ Steer L., Business Licensing and One Stop Shops in Indonesia, THE ASIA FOUNDATION (Jakarta, Indonesia: Economic Programs 2006).

${ }^{15}$ Eyiah A., Regulation and Small Contractor Development a Case of Ghana, (University of Manchester, Manchester 2004).

${ }^{16}$ World Bank, Good Practices for Construction Regulation and Enforcement Reform: Guidelines for Reformers, INVESTMENT CLIMATE REPORT NUMBER: 77100, WORKING PAPER

(Washington, D.C., USA: World Bank Group 2013a). Available at http://documents.worldbank.org (last visited Mar. 01, 2016).

${ }^{17}$ Mensah S., Aboagye K., Addo E., \& Buasti S., Corporate Governance and Corruption in Ghana, Empirical Findings and Policy Implications, (Accra, Ghana 2003).

${ }^{18}$ Freiku S. R., Town and Country Department to Issue Building Permits in Three Months, (Accra, Ghana: Agency Ghana News 2009). Available at http://www.ghanabusinessnews.com/2009/06/21/town-country-department-to-issue-building-permitsin-three-months/ (last visited Mar. 01, 2016).

${ }^{19}$ WORLD BANK AND IFC, DEALING WITH CONSTRUCTION PERMITS (Washington, D.C., USA: World Bank Group and International Finance Corporation 2013). Available at http://www.doingbusiness.org/data/exploretopics/starting-a-business (last visited Feb. 20, 2016).
} 
of the country apart from the capital city, it could go as long as 1-2 years. ${ }^{20}$ The applicant goes through 18 cumbersome procedures. Some stubborn and impatient developers blatantly ignore or resist development abatement directives citing delays or difficulties in securing the permits to justify their illegal development. Individuals and corporate developers have stories to recount about the level of frustration and cost incurred due to the numerous follow ups and accompanying delays experienced whilst patiently waiting for building permits.

Overly complicated construction rules also can increase opportunities for corruption. ${ }^{21}$ World Bank Enterprise Survey data show that, the share of firms expecting to give gifts in exchange for construction approvals is correlated with the level of complexity and cost of dealing with building permits. ${ }^{22,23}$ More efficient systems can therefore prepare governments to take advantage of a pickup in construction activity. Generally speaking, reducing delays benefit more than just builders and owners. A study in the United States estimates that, accelerating permit approvals by three months in a 22-month project cycle could increase construction spending by $5.7 \%$ and property tax revenue for local governments by $16 \%{ }^{24,25}$

\section{B. Data availability, Accessibility and Validity}

One-stop shop is a data storage bank/unit with various linkages which can be accessed by land agencies and other stakeholders. ${ }^{26,27}$ Though this system is available in Ghana, permit agencies find it difficult to access this

\footnotetext{
${ }^{20}$ Kpamma E. Z., \& Adjei-Kumi T., Construction Permits and Flow of Projects within the Sunyani Municipality, Ghana, PROCEEDINGS INTERNATIONAL GROUP ON LEAN CONSTRUCTION (IGLC) 257-266 (Fortaleza, Brazil: IGLC 2013).

${ }^{21}$ Kenny C., Construction, Corruption, and Developing Countries, WORLD BANK POLICY RESEARCH WORKING PAPER 4271 (Washington, D.C., USA: Word Bank 2007). Available at http://econ.worldbank.org (last visited Mar. 08, 2016).

${ }^{22}$ Enterprise Surveys, TOP 10 BUSINESS ENVIRONMENT CONSTRAINTS (The World Bank 2010). Available at $\mathrm{http}: / / \mathrm{www}$.enterprisesurveys.org (last visited Mar. 28, 2015).

${ }^{23}$ Steer L., Business Licensing and One Stop Shops in Indonesia, THE ASIA FOUNDATION (Jakarta, Indonesia: Economic Programs 2006).

${ }^{24}$ BUREAU OF LABOR STATISTICS, OCCUPATIONAL EMPLOYMENT STATISTICS (OES)

(United State Department of Labor 2010). Available at http://www.bls.gov/oes/ (last visited Feb. 26, 2016).

${ }^{25}$ Pricewaterhouse Coopers, Economic Impacts of Accelerating Permit Processes on Local Development and Government Revenues, (Washington, D.C., USA: American Institute of Architect 2005).

${ }^{26}$ Asiedu S. B., \& Agyeman S., Re-engineering the Processing of Building Permits to Control the Development of Unauthorized Structures in the Ghanaian Communities, PROCEEDINGS OF SUNYANI POLYTECHNIC LECTURE SERIES V. APPLIED SCIENCE AND TECHNOLOGY FOR DEVELOPMENT OF GHANA (Sunyani, Ghana: Sunyani Polytechnic 2009).

${ }^{27}$ Forkuo E. K., \& Asiedu S. B., Developing a One Stop Shop Model for Integrated Land Information Management, 29(3) JOURNAL OF SCIENCE AND TECHNOLOGY 114-125 (2009).
} 


\section{ARE THE CHALLENGES IN THE PROCESSING 345}

data. Either the data is not fully integrated or there is fight for supervising authority as a result of jurisdiction problems, faced by Land Commission belonging to Ministry of Lands and Forestry and TCPD in contrast, belonging to Ministry of Local Government. There were also no mechanisms to check the validity of some of the documents submitted by clients. The reproduction of site plans from an existing site plan was not a proper practice because those plans have inherent errors. The application forms are completed by draughtsman; this should have been done by a Licensed Quantity Surveyor or done under his supervision. ${ }^{28}$

Where the data integration has properly been done and systems are working, data is deployed in Geographic Information Systems (GIS) environment with Geodatabase (Spatial and Non-Spatial) having the following themes: layout scheme (parcel information), land use and land cover, land area, topographical maps, cadastral plans, geodetic control network, soil maps, and other relevant field information. In the one-stop shop, institutions such as the TCPD, Geomatic Department (Survey Department), Office of the Administrator of Stool Lands (OASL), Lands Commission, Municipal Assembly, Environmental Protection Agency (EPA), and so forth will be hooked to a central data storage unit. That is, an officer in any of the above institutions can have access to all land information and other related matters without physically moving from one office to another. Take a parcel in Baakoneaba in the SEM in the one-stop shop for example, will have a unique identifier, title holder's name, topographic information of the land, purpose of demarcation, geodetic network information, geotechnical information, Land Area and so on, as first-hand information to the Senior Officer involved in issuing the building permits. Therefore instead of files moving from one institution to another, soft copies will be used instead.

\section{Lack of Coordination Between the Land Agencies and the Local Authorities}

Before a building plan is approved, appropriate clearances are needed to ensure quality and safety. Often several agencies are involved. To prevent overlap and ensure efficiency, many economies have opted to put the agencies in one location. These one-stop shops improve the organization of the review process - not by reducing the number of checks needed but by better coordinating the efforts of different agencies. That way, more

\footnotetext{
${ }^{28}$ GOVERNMENT OF GHANA, BUILDING REGULATIONS OF GHANA LI 1630 (Accra, Ghana: Ministry of Works and Housing 1996).
} 
resources can be devoted to safety checks rather than to manual paper works. ${ }^{29}$ Allotted to Hammah ${ }^{30}$, acquisition of lease documents or title, to necessitate the granting of a permit is difficult in Ghana.

Lengthy processing durations and high cost deter developers from applying for permits. Many developers are even unaware of laws on housing. Many old and emerging communities have no planning permission. Certain communities have multiple planning schemes and multiple land sales making plan implementation difficult. ${ }^{31}$ Search for ownership at the lands commission can be very cumbersome because "people" are registered instead of the land. If land parcels are given unique serial numbers like cars and any other products from manufactures, and duly registered duplication or multiplication problems will be greatly minimized. This was the disturbing building permit state in most cities in the country. These problems can be attributed to apparent lack of coordination between land agencies and local authorities in planning land use at various levels of land development. Thus according to building development administration in Kumasi Township $80 \%$ of buildings in the Metropolis were without building permits in 2009. Between 1990 and 2000, only 7.2\% of buildings in the Metropolis had permits. ${ }^{32}$

\section{Inadequate Number of Staff for Field Inspection and Monitoring}

This was the most crucial and yet serious challenge that, the permit acquisition process faced in Ghana. The number is woefully inadequate and their capacity is not strongly built, meanwhile, ownership verification of parcel of interest at the Lands Commission has to be done. Interestingly, this is the last test that the application must go through. Additionally, the monitoring unit of the building inspectorate division was tasked with the responsibility of ensuring that developers comply with building drawings submitted to the assembly during the permit acquisition process, and report any unauthorized structural development within their area of jurisdiction to

\footnotetext{
${ }^{29}$ World Bank, Doing Business 2013: Smarter Regulations for Small and Medium-Size Enterprises, CREATIVE COMMONS ATTRIBUTION CC BY 3.0 (Washington, D.C., USA: World Bank Group 2013b). doi:10.1596/978-0-8213-9615-5

${ }^{30}$ Hammah N. K., Re-echoing Building Permits, PERMIT JOURNALS TO REVAMP PUBLIC CONSCIOUSNESS (2010). Available at http://wavesint.org/?s=re-echoing+building+permitsitle (last visited Feb. 25, 2016).

${ }^{31}$ Forkuo E. K., \& Asiedu S. B., Developing a One Stop Shop Model for Integrated Land Information Management, 29(3) JOURNAL OF SCIENCE AND TECHNOLOGY 114-125 (2009).

${ }^{32}$ Freiku S. R., Ghana: Kumasi's Development Getting Worse, Chaotic, REPORT PUBLISHED FOR LOCAL GOVERNMENT AND ASSEMBLY DELIBERATION (Accra, Ghana: Ghana News Agency (GNA) 2003).
} 
Municipal Planning Authorities. Since their number is small, most of this field inspection and monitoring activities are haphazardly done, leaving most illegal developments unnoticed. The slow verification also caused unnecessary delays to the granting of the permit by the SPC. Local authorities have also put forward many justifications for such delays. ${ }^{33}$ These challenges are actually serving as precursor for the disturbing springing-up of informal structures in most cities in the country.

\section{E. Technological Challenges}

The lack of modern ways such as using Information Communication Technology (ICT) for keeping and retrieving land records at the lands commission was worrying. ${ }^{34}$ Effective and efficient use of information technology can reduce the regulatory cost of construction. Jurisdictions across the United States are using information technology to increase efficiency. More than 500 now use an advanced e-permit processing system. Introduced since 2003, the system has reduced the time that professionals in the construction industry spend on permits by $30 \%$ to $40 \%{ }^{35}$

Economies in the Middle East and North Africa that made dealing with building permits easier focused on introducing online services and electronic platforms. ${ }^{36}$ In East Asia and the Pacific, Singapore, Bahrain and Hong Kong SAR (China) converted their one-stop shops for building permits to online systems in $2008 .{ }^{37}$ Though Ghana has introduced the onestop shop, improvements are yet to be seen.

The City Council of Nairobi (CCN) traditionally only accepted building permits applications manually. The system was believed to be cumbersome and time-consuming and that it encouraged evasion and proved detrimental to the overall economy until the implementation of the e-

\footnotetext{
${ }^{33}$ Hammah N. K., Re-echoing Building Permits, PERMIT JOURNALS TO REVAMP PUBLIC CONSCIOUSNESS (2010). Available at $\mathrm{http}$ ///wavesint.org/? $\mathrm{s}=\mathrm{re}-\mathrm{echoing}+$ building+permitsitle (last visited Feb. 25, 2016).

${ }^{34}$ Kpamma E. Z., \& Adjei-Kumi T., Construction Permits and Flow of Projects within the Sunyani Municipality, Ghana, PROCEEDINGS INTERNATIONAL GROUP ON LEAN CONSTRUCTION (IGLC) 257-266 (Fortaleza, Brazil: IGLC 2013).

${ }^{35}$ BUREAU OF LABOR STATISTICS, OCCUPATIONAL EMPLOYMENT STATISTICS (OES) (United State Department of Labor 2010). Available at http://www.bls.gov/oes/ (last visited Feb. 26, 2016).

${ }^{36}$ WORLD BANK AND IFC, DEALING WITH CONSTRUCTION PERMITS (Washington, D.C., USA: World Bank Group and International Finance Corporation 2013). Available at

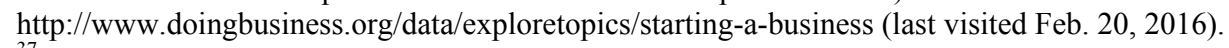
${ }^{37}$ Ministry of Works, Municipalities Affairs and Urban, Building Permit, (Manama, Kingdom of Bahrain 2015). Available at http://www.municipality.gov.bh/ (last visited Feb. 26, 2016).
} 
Building Permit system. ${ }^{38}$ Key steps in the process include: "submission by architects for design approval; evaluation and approval within the $\mathrm{CCN}$; monitoring status of submitted proposal using SMS and email; and issuance of the building permit. The system includes management reporting at all stages of evaluation as well as archiving of building proposals submitted. The data capture and retrieval functions enabled as part of the new system are vital to potential investors and entrepreneurs. The new system allows investors to access statistics on property development trends in Nairobi. It also provides a platform for the profiling of architects so users can identify those who see development projects to successful completion. Investors will be able to identify growth areas in the city. Because the statistics are online they will be easier to collect and this will foster transparency". The results and impact of the permit automation included: reduction of more than two weeks in time required to obtain building permits, inspections, and occupancy permits, increased industry compliance expected to result in growth of issued building permits beyond the current 400 per month, reduced building permit backlog expected to yield more projects and jobs, eight jobs in local economy are created for every 10 construction jobs, streamlined system will stimulate job growth, increase formalization rates among developers and generate opportunities for greater economic growth.

\section{F. Financial Constraints}

Financial resources to develop the agencies capacity, introduce modern technologies, do field inspection and monitoring, purchase logistics, and the like were lacking. Sole funding source over the years has being the government through taxes. Budget allocations to this sector have been inadequate. ${ }^{39}$ At this time, the agency is saddled with huge financial drawbacks. Though the LAP was receiving cooperate funding from external donors, fund flows sometimes halt the project derailing the project

\footnotetext{
${ }^{38}$ World Bank, Automating Kenya's Permits System under the Theme: Information and Communication Technology. Kenya Investment Climate Program with Support from World Bank Group in Partnership with the European Union, the Netherlands, and the United Kingdom, (Nairobi, Kenya 2011a). Available at http://www.wbginvestmentclimate.org (last visited Mar. 12, 2016). ${ }^{39}$ Ghanadistricts, Building Permits (1): Public Concerns the Assemblies Must Address, A PUBLICPRIVATE PARTNERSHIP PROGRAMME BETWEEN MINISTRY OF LOCAL GOVERNMENT AND RURAL DEVELOPMENT (Accra, Ghana: Media, Development and Maks Publications \& Services 2006). Available at http://www.ghanadistricts.com/home/? $=49 \& \mathrm{sa}=4639$ (last visited Feb. 20, 2016).
} 
deadline. ${ }^{40}$ To improve the performances of these agencies in service delivery, drastic investments in ICT and capacity building for workers must be carried out. This is because the current state of encroachment on both public and private lands is quiet disturbing. This will save future governments the headache of drafting demolition guidelines or regulations.

\section{G. Poor Feedback Systems}

The 1996 National Building Regulation L. I. 1630 Section 8 (1 and 2) was fashioned out as follows: "Where a person submits an application for a building permit the District Planning Authority shall notify him within seven days of the receipt of the application, and shall within a period of three months thereafter notify the applicant whether the application is granted or refused". It goes on to conclude that, "an applicant not informed about the grant or refusal of his/her application may after the expiry of the three months commence development on the basis that, the application is acceptable to the District Planning Authority". Clearly this seemly controversial Clause in the regulation seeks to introduce checks and balances by putting permit issuing authorities into action to avoid unreasonable delays whilst keeping applicants abreast with any weighty matter related to each building permit application. ${ }^{41,42}$ Although this is brightly stated in the L. I. 1630, the implementation has not been effective. Ghana Institute of Architects (GhIA) are of the view that planning committees that consider and approve building permits most often fail to meet local authorities, but should be made to display every month permit applications received, approved or refused. The Ministry of Works and Housing and the Ministry of Local Government should ensure that Town Development Committees issue out only development permits whilst building permits become the sole prerogative of town and municipal assemblies to forestall the duplication of delays observed. ${ }^{43}$ These are

\footnotetext{
${ }^{40}$ World Bank, Implementation Completion and Results Report. Report No.: ICR00002083. Ministry of Lands and Forestry, Land Administration Project (LAP), (Washington D.C., USA: The World Bank 2011b).

${ }^{41}$ Hammah N. K., Re-echoing Building Permits, PERMIT JOURNALS TO REVAMP PUBLIC CONSCIOUSNESS (2010). Available at $\mathrm{http} / /$ wavesint.org/? $=$ re-echoing+building+permitsitle (last visited Feb. 25, 2016).

${ }^{42}$ GOVERNMENT OF GHANA, BUILDING REGULATIONS OF GHANA LI 1630 (Accra, Ghana: Ministry of Works and Housing 1996).

${ }^{43}$ Ghanadistricts, Building Permits (1): Public Concerns the Assemblies Must Address, A PUBLICPRIVATE PARTNERSHIP PROGRAMME BETWEEN MINISTRY OF LOCAL GOVERNMENT AND RURAL DEVELOPMENT (Accra, Ghana: Media, Development and Maks Publications \& Services 2006). Available at http://www.ghanadistricts.com/home/? $=49 \& \mathrm{sa}=4639$ (last visited Feb. 20, 2016).
} 
laudable ideas as efficient permit systems elsewhere provide effective feedback systems where applicants are previewed to the status of their permit applications with a click of a bottom and at the comfort of their homes.

\section{CONCLUSIONS}

The intrinsic challenges identified in building permit acquisition system include: lack of integrated central database management system for permit agencies and analogous institutions involved in the permit processing system, too many processing steps, increased cost of construction and loss of value due to bureaucratic delays, lack of coordination between the land agencies and the local authorities, differing land ownership practices in Ghana, inappropriate feedback systems and inadequate number of staff for the field inspection and monitoring. Overall success rate for 417 applications was $82.3 \%$ in the SEM, and that for SWM considering 466 applications was $99.8 \%$. The deferral rate in the SEM was $5.8 \%$ in every 380 applications considered. Redesigning the current permit system by integrating all the agencies involved in the building permit acquisition process to a central database management system (DBMS) is a highly favored option. This will also assists Local Authorities to get value for money and control the springing-up of unauthorized structures in our towns and cities. 